\title{
LAND AND PROPERTY RIGHTS WITHIN THE URBANISM LAW
}

\section{D.G. ALEXANDRU}

\author{
Dana Georgeta Alexandru ${ }^{1}$ \\ Faculty of Humanties and Social Sciences \\ Departament of International Relations, Political Sciences and Security Studies \\ University "Lucian Blaga" of Sibiu, Romania \\ *Correspondence: D. G. Alexandru, ULBS, Calea Dumbrăvii St., no. 34, Sibiu, Romania \\ E-mail: dana.alexandru.g@gmail.com
}

\begin{abstract}
The study intends to highlight the functions of property rights in relation to the characteristics of urbanism law. The analyse aims to identify the role of public authorities in the production process of planning public policies, under current regulations in force in Romania. Moreover, while the legislation led to confer a social function of property rights, this conception of property rights comes up against the revival of private property, which is likely to complicate the implementation of public planning policies. The social function of the property law, however, could reach its limits in the coming years. Indeed, the jurisprudence appears to give a boost to the individualistic dimension of ownership complicating the achievement of public planning policies.
\end{abstract}

\section{KEY WORDS: PROPERTY LAW, PUBLIC AUTHORITIES, LAND USE PLANNING}

\section{INTRODUCTION}

Ever since the dawn of it's becoming, the society has used its own means to reshape the natural environment and create within it a self-made environment which the authors call "artificial", with volumes, spaces and structures that significantly differ from the natural environment in terms of quality.

In order to overcome the challenge of ruthless exploitation of natural resources and intrusion of the artificial environment ${ }^{2}$ into the natural one (which further leads to chaotic development of urban agglomerations and destruction of large areas) a new approach on the urbanism practices was necessary. This revival has - progressively - reached each and every aspect of urbanism: the purpose, the methods and the scope of application. Although the word "urbanism" is relatively recent, the discipline it designates is very old, and it roots back in the antiquity when it referred to cities with orthogonal, regular shape ${ }^{3}$.

As regards typology of contemporary sources, one may notice that international law is completely silent in this matter and EU law addresses the matters of urbanism and land development only to the extent that consequences exist or influence the environmental law. The Constitution of Romania is quasi used in this matter but it only contains provisions that

\footnotetext{
${ }^{1}$ Beneficiary of the Project financed from Lucian Blaga University of Sibiu research grants LBUS-IRG-2016-02

${ }^{2}$ Elena Maria Minea, Urbanism și amenajarea teritoriului (in English, Urbanism and land development), Training support for remote education, Cluj-Napoca, 2011, p. 24.

3 The word "urbanism" was first used by Ildefonso Cerda, a Catalan engineer, in his work titled Teoría general de la urbanización y aplicación de sus principios y doctrinas a la reforma y ensanche de Barcelona, published in 1867 (briefly, in English, General Theory on Urban Planning). He used the Latin word "urbis" to designate the science of city development.
} 
govern the property right. The regulations that govern the urbanism are of legislative nature but there is no code in this respect, whereas the rules are disparate, incomplete and, in our opinion, anachronistic in some respects.

According to Professor Mircea Duțu "in this stage of its assertion as an autonomous law branch and new science, the Romanian law on urbanism basically represents an right of administrative police meant to prevent the violation of a defined order and concerned with causing the protection rules to be strictly observed".

The urbanism law is to be viewed in the same context as an element of the economic law whenever it offers priority to a plot of land on the ground that it is an economic asset, element or resource. However, it remains quasi silent when it comes to operational urbanism, dynamic aspects of urban morphology and the transformation processes that impact the use of lands, urban extension and regeneration, rehabilitation of historical centers and old neighborhoods etc. ${ }^{4}$

The recent developments go even further and reflect the intention to move on from a real estate-based urbanism to a real life policy in increasingly crowded urban communities. Although urbanism was initially intended to merely respond to some aesthetic considerations and was mainly reserved to architects, it is currently a multi-disciplinary field meant to serve the social, land development and environmental policies. Initially imagined to address the urban soil as part of the real estate law, the urbanism law tends to become a law concerned with the activities developed in connection with it.

The way in which the legal regime of urbanism has evolved and developed reflects a limitation of the ownership title in an increasingly restrictive manner, so that the owner had to give in to the public good (just like it happened for the right to build - as a sub-division of the ownership title) and to offer guarantees to the administered communities ${ }^{5}$.

The problem with regulations governing the urbanism is very sensitive and complex because it is "organically" linked to property related matters. One of the major issues that urbanism has to cope with is the manner in which the principles governing the two types of property - the public and private property ${ }^{6}$ - may be made compatible, because whenever implementation of local communities projects is sought, the rights of landlords may very easily be prejudiced.

In Romania, the property right is defined in article 555 of the Civil Code, according to which "(1) Private property means the right of the holder to possess, use and dispose of an asset in an exclusive, absolute and permanent way, within the limits set by the law. (2) Under the law, the private property right can be subject to terms and conditions and subdivisions, where appropriate".

A New Civil Code ${ }^{7}$ has been recently adopted in Romania which dedicates a whole chapter to the issue of legal and conventional limitations of the property right. In our opinion, the limitations set by the law become compatible with the land development objectives sought by the local communities, but the adjustment to the practical situations of space

\footnotetext{
${ }^{4}$ Interview with Professor Mircea Duțu, PhD, published on www.juridice.ro.

${ }^{5}$ Elena Maria Minea, Urbanism și amenajarea teritoriului (in English, Urbanism and land development), Training support for remote education, Cluj-Napoca, 2011, p. 44.

${ }^{6}$ As regards assets which, by law or by their nature, are of public use or interest (according to article 1 of Law 213/1998 on public property and legal framework thereof), the public property right belongs to the state or to the administrative and territorial units.

${ }^{7}$ The Civil Code of July $17^{\text {th }}, 2009$, adopted by Law 287/2009, published in the Official Journal, Part I, no. 505 of July $15^{\text {th }}$, 2011.
} 
organization is often difficult because the specific regulations do not offer instruments to support the administrative practice in this respect.

The Romanian regulations in the matter do not provide for a definition of either the urbanism or the land development and they merely indicate the content, specific features, objectives thereof and means to achieve them. For instance, according to article 2(3) of Law $350 / 2001$ on land development and urbanism " "The space management of the territory is achieved through land development and urbanism which are sets of complex activities of general interest that facilitate the balanced space development, the protection of natural and built-in patrimony and the improvement of living conditions in urban and rural localities".

It may be inferred from the above quoted text that the urbanism ${ }^{9}$ is one of the two instruments (the other one being land development) that help achieving the space management of the territory, with the complex role stated in the above mentioned acts.

A review of the specific activities of urbanism and land development allows us to identify the formal features of the urbanism law. According to most authors, the urbanism law shall remain a law for the constantly expanding city ${ }^{10}$, a specialized, technical and permanently changing sub-division of the administrative law, which confines the property right.

\section{DEMOCRATIC AND PROSPECTIVE CHARACTER}

The specific published literature ${ }^{11}$ defines openness as a phenomenon which allows outside opinions and ideas to be absorbed and transparency as a means to reflect the public character of public administration's actions and efforts to meet half way the community's needs by direct and immediate access and the participation of diligent persons in the decision making process ${ }^{12}$.

The constantly growing role of local communities in the public life doubled by the transfer to them of some urbanism related competencies is also manifest in the recent developments of the legislation which proposed mechanisms intended to strengthen the democratic functioning of local institutions ${ }^{13}$, substantiated by and implemented through some international ${ }^{14}$ and domestic ${ }^{15}$ legal instruments.

\footnotetext{
${ }^{8}$ Updated Law 350/2001 on land development and urbanism, published in the Official Journal no. 373 of June $10^{\text {th }}$, 2001, as supplemented and amended from time to time.

${ }^{9}$ According to article 4 of Law 350/2001 urbanism must be (a) an operational activity intended to assure on site detailing and delimitation of the provisions of the land development plans; (b) an integrated activity which summarizes the sectoral policies on management of localities' lands; (c) a standard-setting activity which states the methods for the use of lands, the definitions of destinations and overall dimensions of buildings, inclusively the infrastructure, the layout and plantations.

${ }^{10}$ Norbert Foulquier, Comment caractériser le droit de l'urbanisme français après la loi SRU. Une analyse historique du droit contemporain de l'urbanisme (in English, How to Characterize the French Urbanism Law in Light of SRU Law. A Historical Approach to Contemporary Law on Urbanism), http://www.univparis1.fr/fileadmin/cerdeau/son/Les_caract\%C3\%A9ristiques_du.

${ }_{11}$ Dana Alexandru, Comunitățile locale și rolul lor în spațiul administrativ european în contextul descentralizării administrative (in English, Local Communities and their Role in the European Administrative Space in the Context of Administrative Decentralization), Pro Universitatia publishing house, Bucharest, 2013, p. 72.

12 Emil Bălan, Drept administrativ și procedură administrativă (in English, Administrative Law and Administrative Proceedings), Ed. Universitară publishing house, Bucharest, 2002, p. 148.

${ }^{13}$ A recent act in this respect is Order 2701/2010 published in the Official Journal of Romania, Part I, no. 47/2011 approving the Methodology for dissemination and public consultation regarding the elaboration or revision of land development plans and urbanism plans.

${ }^{14}$ The European Charter of Local Self-Government adopted in Strasbourg on October $15^{\text {th }}$, 1985, became effective on September $1^{\text {st }}$, 1988. Romania signed the Charter on October $4^{\text {th }}, 1994$ and ratified it by Law 199 of November $17^{\text {th }}, 1997$, published in the Official Journal or Romania, Part I, no. 331 of November $26^{\text {th }}, 1977$, except for article 7(2) of this European act.

${ }^{15}$ Article 120 of the Constitution of Romania, revised.
} 
The decentralization of urbanism reflects a closer relation between the administered communities and the local authorities entrusted with the issuance of urbanism documentations, which further leads to the need to create leverages for the public to be able to participate in the elaboration of such norms. These efforts materialized ${ }^{16}$ into some specific rules implemented in terms of the right to be informed, the right to file petitions and the right of citizens to be consulted.

This reform is intended to improve the decision-making process in a field that impacts the sustainable development of the territory, to improve the view on the realities of the administrative system and to enhance the ability to analyze and summarize the information provided by citizens.

Order $2701 / 2010^{17}$ sets forth the methodology regarding the mandatory elements of public dissemination and consultation to be applied in terms of elaboration or revision of urbanism and land development plans, in accordance with article 61 of Law 350/2001 ${ }^{18}$ on land development and urbanism, as further amended and supplemented.

The scope of application of this order is set out in article 2 and refers to the people initiating, elaborating and approving the urbanism and land development plans, as well as to the decision-makers, and applies to all categories of urbanism and land development plans laid down by the law.

The topic of interest for this opinion is set out in article 3, according to which the public must be kept informed and consulted all throughout the elaboration or updating of the urbanism and land development plans, as an inseparable and binding part of the process of initiation, elaboration, permitting and approval of the urbanism and land development documentations.

Lawmakers set out a detailed administrative proceeding which is mandatory for the public authorities and they also laid down severe penalties in case of failure to observe the obligation to inform and consult the public all throughout ${ }^{19}$ the elaboration or revision of urbanism and land development plans.

The mechanisms of participatory democracy are doubled by legal instruments which allow the verification of validity of the administrative acts. Thus, a citizen who considers that either one of his/her rights was prejudiced, is allowed to seek justice before the court vested to rule on contentious and administrative matters which must look into the validity of that administrative decision. Contentious rules in urbanism matters must be improved because, in the absence of a code of laws and of some rules governing the administrative proceedings, the ruling on administrative decisions is very difficult. A practice does exist, but it focuses on the validity of the building permits and not on the regulations applicable to urbanism matters. Applying a censorship to this field is quite difficult because there is political interference in the elaboration of public urbanism policies which makes it rather impossible to examine it in

\footnotetext{
16 Dana Alexandru, Mihaela Olteanu, Democrația locală instituțională. Între consacrare normativă și practică administrativă. Caietul științific nr. 13 al I.S.A Paul Negulescu (in English, Local Institutional Democracy between Standard Setting and Administrative Practice. Scientific Book no. 13 of the Institute for Administrative Sciences Paul Negulescu), Universul Juridic publishing house, Bucharest, 2011, p. 471-480.

${ }^{17}$ Published in the Official Journal of Romania, Part I, no. 47/2011.

${ }^{18}$ Published in the Official Journal of Romania, Part I, no. 373/2011.

${ }^{19}$ According to article 4 of Order 2701/2010 the process has several stages, as follows: a) the preliminary stage - notify the intention to elaborate; b) first stage - document and elaborate the substantiation report; c) second stage - elaborate proposals to be lodged for approval; d) final stage - elaborate the final proposal which takes into account all comments from permit issuers and is subject to the process of decisional transparency.
} 
terms of opportunity, as long as the courts of law are only entitled to determine the validity of the administrative decisions.

In conclusion, the right of citizens to participate in the solving of public issues is well defined in the Romanian law but the Romanian law does not offer the tools necessary to achieve efficiency and effectiveness in terms of urbanism.

The urbanism law is undoubtedly a prospective right by its very nature. Land development - as a general, encompassing activity (which circumscribes the urbanism) must be (in accordance with article 3):

1. A global activity intended to group the various sectoral policies into an integrated set of rules;

2. A functional activity which must take into account the natural and built-in environment based on the culture and mutual interest values;

3. A prospective activity, meant to examine the long-term development trends of economic, environmental, social and cultural phenomena and interventions and take them into consideration during implementation;

4. A democratic activity intended to assure the participation of population and of its political representatives in the decision-making process.

Land development - the purpose of which is to reconcile economic, social, environmental and cultural policies throughout the Romanian territory - is an activity conducted all along Romania, based on the principles of prioritization, cohesion and space integration at national, regional and county level.

Urbanism is intended to stimulate the complex evolution of localities by means of the short, medium and long-term development strategies. Activities are being conducted in all urban and rural localities in accordance with their potential and the expectations of their inhabitants.

The activities conducted are intended to achieve objectives such as: $\mathbf{m}$ improving the living conditions by eliminating all malfunctions, ensuring the access to infrastructure, public services and convenient housing for all inhabitants; - creating conditions for the special needs of children, elderly and disabled persons; - efficiently using the lands in accordance with the adequate urbanism functions; controlled expansion of built-in areas; protecting and leveraging the cultural, built-in and natural patrimony; a ensuring the quality of built-in, developed and planted environment in all urban and rural localities; $\mathbf{a}$ protecting the localities against the acts of God.

Whereas the specific urbanism activities are very complex in reality, they need to be properly "articulated" so that the "whole" system relies on an adequate work and life environment for the members of the community. A very strenuous effort lies ahead the relevant public authorities that must undertake responsibilities for several generations to come $^{20}$.

\section{STAKEHOLDERS IN URBANISM LAW AND DECENTRALIZATION}

The public administration is intended to serve the public interests and by its very nature it must cause the implementation of the political values that express the general

\footnotetext{
${ }^{20}$ Elena Maria Minea, Urbanism și amenajarea teritoriului (in English, Urbanism and land development), Training support for remote education, Cluj-Napoca, 2011, p. 48.
} 
interests of the society organized by the state. Law implementation is a prerogative in the hands of the executive power but it needs help from the public administration.

The Romanian local administration has been constantly concerned with the urbanism matters ever since the publication of the Organic Regulations (1831) based on which there have been created the „city councils” (in Romanian, ,sfaturile orășenești”) the main powers and duties of which were the administration and management of cities in all their areas (street paving, public lighting, urban embellishing actions etc.).

Local public issues have always been entrusted to the public authorities which were given specific powers in this respect.

Hence, the applicable law in the matter of local authorities' competence is Law 215/2001 on local public administration. According to article 3 of this law, the decision-making bodies are vested with the settlement and management of the local public affairs for and on behalf and to the best interest of local communities they represent ${ }^{21}$.

According to the doctrine, the principle of decentralization and subsidiarity governs the allocation of local powers and duties, depending on the right of local communities to make decisions intended to solve problems that fall under their scope of competence. This principle relies on the fundamental rationale that a decision concerning a person's or a community's own interests must be made by that person or community which is the next competent decision implementing factor ${ }^{22}$.

Liability for land development and urbanism falls on the authorities of the central and local public administration. The land development and urbanism activities are entrusted to the public administration because it is the institution called to answer to all kinds of requests and is held liable for the proper management thereof.

It is the local council that examines and approves the land development and urbanism documentations according to the law and determines the material and financial resources necessary to implement them, approves the allocation of funds from the local budget for defense against flood, fire, natural disasters and bad weather consequences.

Furthermore, the local council determines the actions necessary to build, maintain and revamp the roads, bridges and the entire infrastructure of the local interest transportation routes (article 38 ).

According to article 104(1)(j), the county council shall, after consultation with the authorities of local, communal and city public administration, determine the projects for land organization and development for the entire county as well as the projects for general urbanism development of the county and of the administrative and territorial units thereof, and monitors the way in which they are implemented in cooperation with the concerned authorities of local, communal and city public administration.

The Ministry of Regional Development and Public Administration is the authority of the specialized central public administration called to implement the government's development strategy and policy in terms of land development, urbanism, public works and constructions, subject to local autonomy.

Its powers include, among others, the obligation to elaborate the Plan for national territory development as a tool summarizing the sectoral and local policies and plans for land development, the obligation to determine along with the authorities of the central and local

\footnotetext{
${ }^{21}$ According to article 3 of Law 215/2001.

${ }^{22}$ Emil Bălan, Instituții administrative (in English, Administrative Institutions), C.H. Beck publishing house, Bucharest, 2008, p. 30.
} 
public administration their duties and powers and the actions to be taken in order to protect areas of historical, architectural or landscape value.

This authority coordinates the public interest scientific researches in respect of land development, urbanism, enhanced stability and safety of constructions, protection against earthquakes, and coordinates the elaboration, permitting and approval of norms, specifications and technical regulations for the activities that fall under its scope of competence and it also coordinates the verification of the implementation thereof.

Furthermore, this ministry exerts the state control on constructions, public works, urbanism and land development in respect of compliance with the rules governing the authorization of buildings and implementation of the quality system in design, execution, operation and use of constructions.

There are other governmental or non-governmental bodies that join these administrative structures in their efforts to promote and implement the urbanism policies and regulations (inter-ministerial councils, technical councils, the Romanian Union of Architects, the Romanian Professional Association or Urbanists, the Romanian Union of Plastic Artists, other scientific, professional, creation organizations).

\section{EXERCISE OF THE PROPERTY RIGHT WITHIN THE URBANISM LAW}

Human evolution has been and is relying on the property. It is common knowledge that the property right is a complex, constantly evolving notion with various historical, sociological and legal implications.

The literature defines the property right as a right in rem which offers the holder the powers to possess, use and dispose of an asset; the holder is solely entitled to exercise all these powers as he/she may deem fit in his/her own discretion for his/her own benefit subject to the regulations in force ${ }^{23}$.

It is a fact of the modern society that urbanism and property right are interlinked and overlapping - which calls for a thorough analysis of this notion. The legal traits, attributes and sub-divisions of the property right are the basic elements addressed by the regulations governing the land development and planning.

The property right is an absolute right. This absoluteness of the property right results first from its definition in the Civil Code and then from logic. However, as regards its legal content, the property right is not absolute because it is limited by the law, as stated in article 555 par. 1 of the Civil Code, according to which the property right may only be exercised "within the limits set by the law".

Therefore, the expression "absolute" should be read as follows: the property right is opposable to all ${ }^{24}$, that is, erga omnes, but its content is limited ${ }^{25}$.

A French ${ }^{26}$ conclusion of the relevant literature is that the legal force of this right no longer offers guarantees and that social pressure "mutilates the force given by its content".

\footnotetext{
${ }^{23}$ L. Pop, L.M. Harosa, Drept civil. Drepturile reale principale (in English, Civi Law. Main Real Rights), Universul Juridic publishing house, Bucharest, 2006, p. 72.

${ }^{24}$ As regards the larger discussion on opposability of private rights, see I. Deleanu, Părțile și terții. Relativitatea și opozabilitatea efectelor juridice (in English, Parties and Third Parties. Relativity and Opposability of Legal Effects), Rosetti publishing house, Bucharest, 2003.

${ }^{25}$ Marius Văcărelu, Administrația publică și dreptul de proprietate (in English, Public Administration and Property Right), doctoral thesis, p. 44, not published.

${ }^{26}$ https://www.courdecassation.fr/publications 26/rapport annuel 36/rapport 2008 2903/etude discriminations 2910/distin ctions_justifiees_2918/distinctions_entre_proprietaires_2920/limitations_exercice_droit_propriete_12143.html
} 
"The absoluteness of the property right is compromised two times, first by the existing laws and regulations, as stated in article 544 of the Civil Code according to which «property means the right to benefit and dispose of one's own assets in the most absolute manner, unless they are used in a manner prohibited by the law and regulations» and second by the social context according to which «neither the owner nor his/her asset are ever isolated; any property borderlines other properties, other freedoms which inevitably limit it»" (C. Atias) (translation from French).

The property right is a permanent and exclusive right. Exclusiveness, just like absoluteness, is expressly stated in article 555(1) of the Civil Code. Doctrine ${ }^{27}$ also reverts to article 1 of the First Protocol to the European Convention for the Protection of Human Rights and Fundamental Freedoms ${ }^{28}$ which sets out three norms for the protection of the property right:

1. Every natural or legal person is entitled to the peaceful enjoyment of his possessions.

2. No one shall be deprived of his possessions except in the public interest and subject to the conditions provided for by law and by the general principles of international law.

3. States are entitled to enforce such laws as they deem necessary to control the use of property in accordance with the general interest or to secure the payment of taxes or other contributions or penalties.

The norms that guarantee and protect the property are in addition to regulations governing the limitations of the property right: the international law provides for exceptional restrictions that may result in the loss of the property right for public utility.

The content and limitations of the property right in Romanian law are first laid down in article 44 of the Constitution, according to which "Everyone's property right and the claims against the state are protected by law. The content and limitations of these rights are laid down by the law."

The provisions of article 556 of the Civil Code titled "Restricted exercise of the private property right" set out some material and legal limitations. The topic of interest for this opinion is the legal limitation which may represent a normal limitation, generated by the need to protect the general interests of the society or the property rights of the other holders. Under the circumstances, the regulations on urbanism acquire a major role. When examining this issue, the French Court of Cassation concluded that: "The use of the asset by its owner is limited by a public order which sometimes refers to organization and planning and sometimes refers to management. This public order limits both the holder's right to use and his/her right not to use that asset. Any owner of immovable property is subject to the same urbanism restrictions that his/her immovable property is subject to. He/she can only use it in accordance with its destination. The compliance of projects and their execution with the general rules relying on security, hygiene, construction and aesthetic reasons and with the urbanism specifications is controlled a priori by the building permit and a posteriori by the certificates of compliance ${ }^{\text {29 }}$ (translation from French).

A sensitive issue that land development and urbanism have been and are systematically required to cope with is the incompatibility of the principles that govern the two types of

\footnotetext{
${ }^{27}$ M. Rudăreanu, Dreptul bunurilor (Drepturile reale), FRM publishing house, Bucharest, 2006, p. 57.

${ }^{28}$ Convention for the Protection of Human Rights and Fundamental Freedoms, adopted in 1950 and ratified by Romania by Law 30/1994, published in the Official Journal of Romania, Part I, no. 135/1994.

${ }^{29}$ https://www.courdecassation.fr/publications 26/rapport annuel 36/rapport 2008 2903/etude discriminations 2910/distin ctions_justifiees_2918/distinctions_entre_proprietaires_2920/limitations_exercice_droit_propriete_12143.html.
} 
property - public and private: public interest and private interest are often on opposite or even antagonist positions and a simple "call" for a legally diligent person to give in to the general interest can prove to be but an utopic effort.

It was therefore necessary to sort out this "conflict" between the holders of the private property right - who are expected to give in - and the beneficiaries of such "courtesy".

This issue seems to have been solved by the French case law but the discussion on the social function of the property right continues in literature ${ }^{30}$ : "However, the social dimension of the property right within the urbanism law might be exhausted in the near future. In fact, the case law seems to re-boost the individualistic dimension of the property right, which will make it more complicated to implement the public urbanism policies, with the Constitutional Council passing several decisions in this respect. For instance, it has determined that article L.332-6-1 of the Constitution, which allowed the public administration to issue a building permit in exchange for the concession of a plot of land by the claimant, was unconstitutional ${ }^{31}$. Even though this censorship relies on the fact that the lawmaker and not the regulatory authority was called to clarify the regime of this "exchange», this case law testifies of the judge's concern to protect the property right" (translation from French).

This is not the case in Romanian administrative practice. Once they issue the urbanism documentations, the local authorities impose on the landowners who initiated the PUZ the obligation to clarify - until the building permit is released - the legal standing of the land plot to be assigned for the purposes of road bed widening.

The landowners who initiated the urbanism documentation shall execute the "works for planning and revamping of the proposed roads (accesses) at their own expenses. The connections to public urban networks shall be executed by the investor at its own expenses. The building networks referred to above shall, irrespective of the manner in which they are financed, join the public property according to article 29 of Government Decision 525/1996 approving the General Urbanism Regulation" ${ }^{\text {32 }}$.

Landowners do not revert to the courts of law seeking invalidation of these obligations set by the local authorities but, on the contrary, in executing their investments they implement the provisions of the decisions issued by the local councils. This phenomenon is increasingly evolving in Romania. The absence of some specific, urbanism-related, regulations which would provide the players with accurate leverage capable of reconciling the interests of private entities with those of the public administration facilitate the abuse of power by the public authorities.

For the purposes of a profound metamorphosis of the Romanian regulations on the matter it may be very useful to revert to the French regulations and case law $^{33}$ :

"The public utility easements are an important source of differentiation between owners. By definition, an easement is a limitation of the individual property right, because it consists,

\footnotetext{
${ }^{30}$ Norbert Foulquier, Comment caractériser le droit de l'urbanisme français après la loi SRU. Une analyse historique du droit contemporain de l'urbanisme (in English, How to Characterize the French Urbanism Law in Light of SRU Law. A Historical Approach to Contemporary Law on Urbanism), http://www.univparis1.fr/fileadmin/cerdeau/son/Les_caract\%C3\%A9ristiques_du.

${ }^{31}$ Constitutional Council, November $22^{\text {nd }}, 2010$, Decision no. 201033-QPC, Esso SAF: AJDA 2010, p. 2384, comment by F. Rolin, Collection Dalloz, 2011, p. 136, comment by E. Carpentier.

32 Decision no. 85 of March 26 $6^{\text {th }}, 2016$, passed by the Local Council of the Municipality of Sibiu, approving the Zonal Urbanism Plan and the Local Regulation; green area intended to protect the major infrastructure - fuel distribution station "Mol", shopping building (...) without number; initiator: City Hall of Sibiu; investor: MOL Romania Petroleum Product S.R.L.; https://extranet.sibiu.ro/Registratura/Hotarari/Detaliu.aspx?registru=HOT-HCL-SIBIU\&nr=85\&an=2015.

${ }^{33}$ https://www.courdecassation.fr/publications 26/rapport annuel 36/rapport 2008 2903/etude discriminations 2910/distin ctions_justifiees_2918/distinctions_entre_proprietaires_2920/limitations_exercice_droit_propriete_12143.html.
} 
according to article 637 of the Civil Code, in «a fee levied on an estate for the use and benefit of another owner' estate».

It can be natural, conventional or judicial, while remaining legal. The easements established by the law refer either to the public or communal benefit or to the benefit of individuals (article 649 of the Civil Code). The easements created for public utility (article 650 of the Civil Code) are of various types and refer to the transport infrastructures, the electricity distribution, the maritime public domain (...), the urbanism, the environment, the execution of public works etc.

The regime of easements created for public utility is autonomous and laid down in particular laws and regulations whereas the rules governing the easements created for individuals would not be applicable. Hence, a public company in charge with the public service of electricity distribution who unlawfully occupies a land may not argue the acquisition of the easement by prescription ( $3^{\text {rd }}$ civil division, March $7^{\text {th }}$, 2007, Bull. 2007, III, no. 35, appeal no. 05-18.057). On the other hand, the public utility easement does not expire upon the elapse of a 30-year term of non-use of the land".

Although the rationale behind the limitations of the property right remains, it must be outlined that there is also a less aggressive way for the state to acquire the ownership title: the preemption right.

There is limited reference in the Romanian regulations to the preemption right and no such prerogative is offered to the state in terms of urbanism. Such a legislative gap is adversely impacting the intensification and the quality of actions in respect of land management and urban development.

For all these reasons, it is imperative to create the necessary framework which allows the rules and actions intended to assure the urban development in Romania to be reconsidered and implemented on a wider and wider scale in order to keep up with the rapid growth of Europe.

\section{CONCLUSIONS}

In light of these considerations, it is critical for the development of the urbanism law to benefit of legislative changes which would focus on providing legal methods and instruments for urban planning actions and interventions intended to create a "legal system in urbanism" offering adequate principles, regulations, notions and concepts.

Let alone the quasi "procedural" issues, it is appropriate to notice that such an endeavor requires a significant amount of synthesizing and creative efforts. Where the regulations in the matter are relatively poor, incomplete or even inadequate to a certain extent, a highly creative encoding is required, which means a significant amount of new laws.

While struggling to provide a basis for the urbanism law, Romania is simultaneously forced into rapidly adjusting to the new, post-modern, challenges. The assimilation of values and requirements of a "sustainable urbanism development" which means reconciling economic efficiency, environmental protection and social equity, is now doubled by the environmental-climate related requirements ${ }^{34}$.

\footnotetext{
${ }^{34}$ Mircea Duțu, www.juridice.ro.
} 


\section{BIBLIOGRAPHY}

1. Alexandru, D. Colectivităţile locale şi rolul lor în spaţiul administrativ european $\hat{n}$ contextul descentralizării administrative, "PRO Universitaria" Publishing House, Bucharest, 2013;

2. Alpopi, C. Elemente de urbanism, "Ed. Universitară" Publishing House, Bucharest, 2008;

3. Auby, J-B. et Perinet-Marquet, H. Droit de l'urbanisme et de la construction, "Editions Montchrestien", Paris, 2004;

4. Alexandru, D et Olteanu, M. "Democraţia locală instituţională. Între consacrare normativă şi practică administrativă. " Caietul Ştiinţific nr. 13 al I.S.A. Paul Negulescu, "Universul Juridic" Publishing House, Bucharest, 2011;

5. Bălan, E. Drept administrativ şi procedură administrativă, București, Ed. Universitară Publishing House, Bucharest, 2002;

6. Bălan, E. Instituții administrative, "C.H. Beck" Publishing House, Bucharest, 2008;

7. Deleanu, I. Părţile şi terţii. Relativitatea şi opozabilitatea efectelor juridice, "Rosetti" Publishing House, Bucharest, 2003;

8. Minea, M.E. Urbanism şi amenajarea teritoriului. Support de curs pentru învățământul la distanță, Cluj-Napoca, 2011;

9. Pop, L. et Harosa, L.M. Drept civil, Drepturile reale principale, "Universul Juridic" Publishing House, Bucharest, 2006;

10. Rudăreanu, M. Dreptul bunurilor (Drepturile reale), "FRM" Publishing House, Bucharest, 2006;

11. Văcărelu, M. Administraţia publică şi dreptul de proprietate, teză de doctorat, nepublicată, Bucharest, NUSPA, 2010. 